Check for updates

Cite this: New J. Chem., 2020, 44, 1677

Received 13th November 2019, Accepted 6th January 2020

DOI: 10.1039/c9nj05682c

rsc.li/njc

\section{Challenges and benefits of post-lithium-ion batteries}

\author{
Marc Walter, ${ }^{a b}$ Maksym V. Kovalenko (D) *ab and Kostiantyn V. Kravchyk (D) *ab
}

\begin{abstract}
At present, rechargeable batteries composed of sodium, magnesium and aluminum are gaining attention as potentially less toxic and more economical alternatives to lithium-ion batteries. From this perspective, the last two decades have seen a surge of reports on various anodes and cathodes for post-lithium-ion batteries, including sodium-, magnesium-, and aluminum-ion batteries. Moreover, the new electrochemical concept of dual-ion batteries, such as magnesium-sodium and aluminum-graphite dual-ion batteries, has recently attracted considerable attention. In this focus article, the operational mechanisms of post-lithiumion batteries are discussed and compared with lithium-ion technology, along with core challenges currently limiting their development and benefits of their practical deployment.
\end{abstract}

\section{Introduction}

To decrease carbon dioxide emissions, unprecedented research is being undertaken to develop efficient and inexpensive electric vehicles and stationary energy-storage systems for energy generated by intermittent (renewable) sources such as wind and solar power. ${ }^{1,2}$ In this regard, increasingly batteries based on sodium $(\mathrm{Na})$, magnesium $(\mathrm{Mg})$, and aluminum (Al) are drawing attention due to the high abundance of these elements on Earth and therefore their potentially overall lower cost compared to lithium (Li)-ion batteries (LIBs), which represent the current commercial standard. ${ }^{3,4}$ However, replacing Li-ions with $\mathrm{Na}-, \mathrm{Mg}-$, or Al-ions requires deep revision and re-exploration of the cathode and electrolyte materials and electrochemistry of such batteries. Herein, we briefly review emerging battery technologies based on Earth-abundant elements-excluding already mature systems such as lead-acid and sodium-sulfur batteries as well as post-Li-ion batteries based on sulfur/air cathodes-and discuss their respective advantages and disadvantages. It is recognized that batteries based on potassium $(\mathrm{K})$ begin attracting attention as a low-cost battery technology, ${ }^{5}$ but for the sake of conciseness it will be omitted from this short focus article.

The operating principle of a rechargeable battery is based on a reversible redox-reaction between an anode material (negative electrode, "reductant") and a cathode material (positive material, "oxidant"). The anode and the cathode material are spatially

\footnotetext{
${ }^{a}$ ETH Zürich, Department of Chemistry and Applied Biosciences, Vladimir Prelog Weg 1, 8093 Zürich, Switzerland. E-mail: kravchyk@inorg.chem.ethz.ch, mvkovalenko@ethz.ch

${ }^{b}$ Empa-Swiss Federal Laboratories for Materials Science and Technology, Laboratory for thin films and Photovoltaics, Überlandstrasse 129, 8600 Dübendorf, Switzerland
}

separated but connected electrically through an external electrical circuit and ionically through the electrolyte. Fig. 1a shows the fundamental operating principle for a battery with graphite as the anode material and lithium cobalt oxide $\left(\mathrm{LiCoO}_{2}\right)$ as the cathode material (the materials used in most commercial LIBs). For a LIB, the transfer of electrons from the anode to the cathode side is accompanied by the extraction of Li-ions from the anode material and their insertion into the cathode material to balance the charge. Hence, anode and cathode need to be connected ionically by a Li-ion containing electrolyte. The reactions that occur during discharge of the battery are:

$$
\begin{gathered}
\text { Anode: } \mathrm{LiC}_{6} \rightarrow \mathrm{C}_{6}+\mathrm{Li}^{+}+\mathrm{e}^{-} \\
\text {Cathode: } x \mathrm{Li}^{+}+x \mathrm{e}^{-}+\mathrm{Li}_{1-x} \mathrm{CoO}_{2} \rightarrow \mathrm{LiCoO}_{2}
\end{gathered}
$$

Overall reaction: $x \mathrm{LiC}_{6}+\mathrm{Li}_{1-x} \mathrm{CoO}_{2} \rightarrow x \mathrm{C}_{6}+\mathrm{LiCoO}_{2}$

Upon charging, the processes are reversed and both Li-ions and electrons are extracted from the cathode and reinserted into the anode material. Because the same ions migrate during both charge and discharge processes, such devices are often referred to as "rocking-chair" cells. Importantly, despite its high capacity metallic $\mathrm{Li}$ is not used in commercial rechargeable LIBs for safety reasons. Li is prone to forming branch-like structures (dendrites) during cycling, which can result in short-circuiting of the cell and consequently even explosion of the battery. ${ }^{6-8}$ Important electrochemical parameters that determine the energy density $\left(E_{\text {cell }}\right)$ of such a cell are the specific/volumetric capacities of the anode and cathode materials $\left(C_{\text {Anode }}\right.$ and $C_{\text {Cathode }}$, respectively) and cell voltage $\left(U_{\text {cell }}\right)$, which are related by $E_{\text {cell }}=C_{\text {cell }} U_{\text {cell }}$, where $C_{\text {cell }}=C_{\text {Anode }} C_{\text {Cathode }} /\left(C_{\text {Anode }}+C_{\text {Cathode }}\right)$. $C_{\text {Anode }}$ and $C_{\text {Cathode }}$ express the amount of charge that can be extracted from the respective electrodesper unit of their mass/volume. $U_{\text {cell }}$ is determined by the difference between 

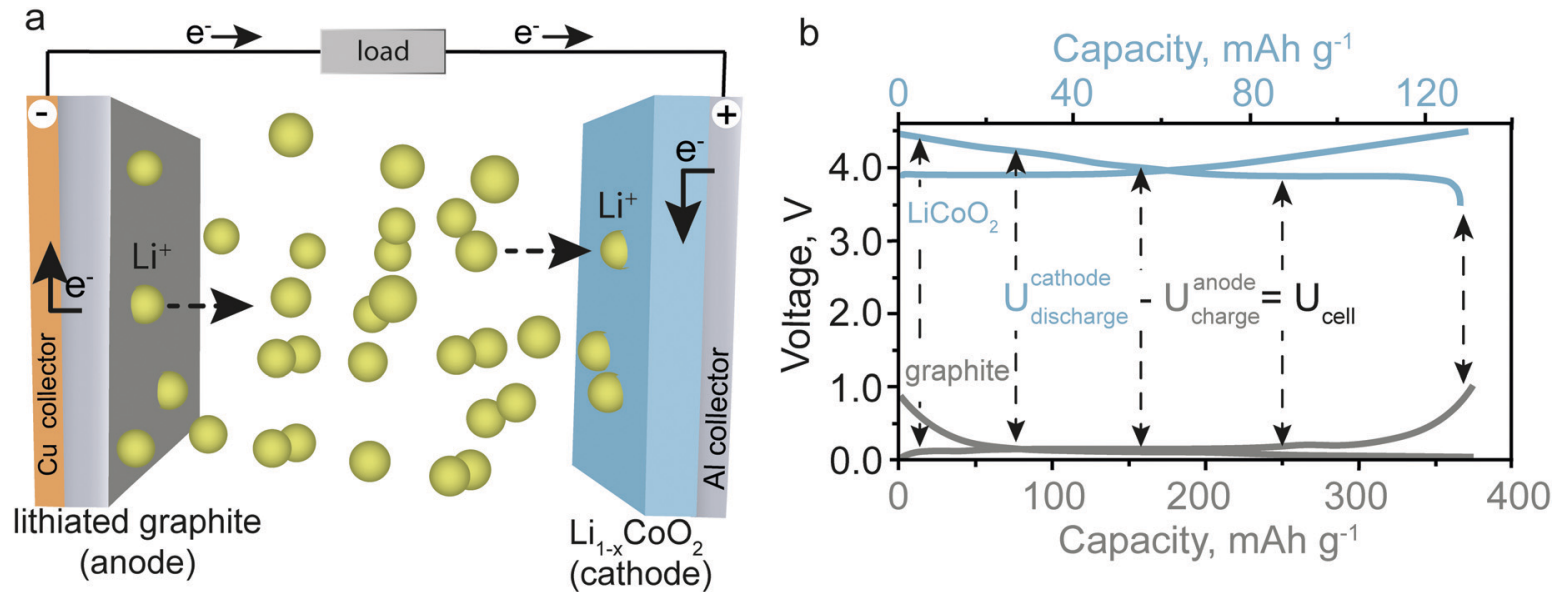

Fig. 1 (a) Schematic illustrating the operating principle of a rechargeable LIB with graphite as the anode material and LiCoO 2 as the cathode material. (b) Galvanostatic charge/discharge curves of $\mathrm{LiCOO}_{2}$ and graphite measured in combination with metallic lithium as counter and reference electrodes (half-cell configuration)

the average charging voltage of the anode (delithiation) and the average discharge voltage of the cathode (lithiation), which are both measured versus metallic Li (Fig. 1b). Apart from $E_{\text {cell }}$ of a cell, there are numerous important electrochemical criteria that have to be considered such as long-term cycling performance (cycle life), coulombic efficiency, energy efficiency, and power density. Moreover, because values such as energy and power densities are related to the mass/volume of the electrode materials, the mass/volume of all the components in practical cells has to be considered. For instance, while the theoretical energy density of a graphite/ $/ \mathrm{LiCOO}_{2}$ cell is $c a .400 \mathrm{~W} \mathrm{~h} \mathrm{~kg}^{-1}$, to estimate its practical energy density, this value should be decreased by $40-60 \%$ to account for the weight of inactive components of the cell such as the electrolyte, current collectors, separator, and packaging. ${ }^{9}$ For practical applications, further equally important factors are safety, environmental friendliness, and capital cost (\$ per $\mathrm{kW} \mathrm{h}$ ) of the battery.

\section{Sodium-ion batteries}

Sodium-ion batteries (SIBs) have the most similarities with LIBs in terms of their typical electrode materials and electrolyte formulations. However, despite their proximity in the periodic table, the electrochemistries of Na- and Li-ions are often very different because the radius of an $\mathrm{Na}$ ion is $\sim 50 \%$ larger than that of an $\mathrm{Li}$ ion. For instance, sodium cobalt oxide $\left(\mathrm{NaCoO}_{2}\right)$, which is the direct Na-ion analog of $\mathrm{LiCoO}_{2}$, shows poorer electrochemical cycling performance and has much lower discharge/charge voltages than those of $\mathrm{LiCoO}_{2} \cdot{ }^{10}$ Nevertheless, new efficient Na-ion cathode materials have been successfully developed, such as $\mathrm{Na}_{1.5} \mathrm{VPO}_{4.8} \mathrm{~F}_{0.7}{ }^{11}$ and $\mathrm{Na}_{4} \mathrm{Co}_{3}\left(\mathrm{PO}_{4}\right)_{2} \mathrm{P}_{2} \mathrm{O}_{7}{ }^{12}$ which show electrochemical performance comparable with that of the best Li-ion cathodes. The issue at hand for SIBs has been the development of high-performance anode materials. Similar to metallic $\mathrm{Li}$, the use of elemental $\mathrm{Na}$ as an anode is not possible because of the problem of $\mathrm{Na}$ dendrite formation (Fig. 2). In addition, graphite, which serves as an anode material for LIBs, shows negligible capacities of $30-35 \mathrm{~mA} \mathrm{~h} \mathrm{~g}^{-1}$ for Na-ion storage. ${ }^{13}$

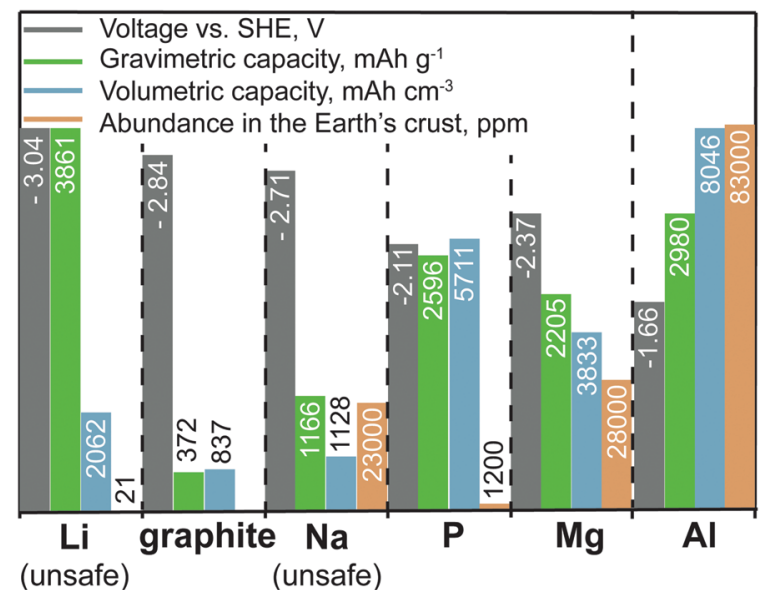

Fig. 2 Comparison of the voltage vs. standard hydrogen electrode (SHE), specific and volumetric capacities, and Earth abundance of various anode materials. As elemental lithium and sodium cannot be used safely in rechargeable batteries because of dangerous dendrite formation, graphite (for Li-ion storage) and phosphorus (for $\mathrm{Na}$-ion storage) are listed as potential substitutes. ${ }^{19,20}$ The voltages given for graphite and phosphorus correspond to their lithiated (graphite) and sodiated (phosphorus) state. We note that unlike in aqueous systems, where the $\mathrm{Al}^{3+} / \mathrm{Al}$ potential is $-1.66 \mathrm{~V}$ vs. SHE, its value shifts markedly in chloroaluminate ionic liquid electrolytes to about $-0.7 \mathrm{~V}$ vs. SHE $\left(2.3 \mathrm{~V}\right.$ vs. $\left.\mathrm{Li}^{+} / \mathrm{Li}\right){ }^{21}$ Even though graphite is a naturally occurring material, its abundance is not given in the graph. We also note that high-quality graphite is available as an industrial side product.

Other carbonaceous materials such as hard carbon exhibit capacities of less than $300 \mathrm{~mA} \mathrm{~h} \mathrm{~g}^{-1}$ at rather low current rates and suffer from low tap density. Although they often exhibit lower capacities for Na- than for Li-ion storage, alloying-type anodes composed of elements such as tin ( $\mathrm{Sn})$, antimony (Sb), or phosphorus (P), have also been intensively studied as promising anode materials. ${ }^{14-17}$ However, such anodes often suffer from poor cycling stability caused by their massive volume changes upon discharge/charge (alloying/dealloying), which leads to rapid mechanical deterioration of the electrodes. For instance, in the 
case of $\mathrm{Sb}$, the sodiation reaction $\left(3 \mathrm{Na}^{+}+3 \mathrm{e}^{-}+\mathrm{Sb} \rightarrow \mathrm{Na}_{3} \mathrm{Sb}\right)$ has a volume change of almost $300 \%$. Employing nanosized or nanostructured forms of the active material has been demonstrated as an effective strategy to overcome this problem, ${ }^{18}$ yet it is questionable whether such methods are sufficiently costeffective to be implemented on the industrial scale. Since the only advantages of SIBs are the low cost of sodium salts and the fact that low-cost $\mathrm{Al}$ current collectors can be used on the anode side (because $\mathrm{Na}$, unlike $\mathrm{Li}$, does not alloy with $\mathrm{Al}$ ), many electrode materials developed to date for SIBs are unsuitable for the use in commercial cells considering the relatively high cost of their preparation. Other anode materials, despite showing high capacities, suffer from relatively high desodiation voltages, leading to low cell voltage of the respective full cell. Finally, some anodes face issues in terms of safety. For instance, $P$ offers a high specific capacity and relatively low desodiation potential, making it a compelling anode material.

However, in the charged state, $\mathrm{P}$ is converted into $\mathrm{Na}_{3} \mathrm{P}$, which readily reacts with water (in the case of cell breakage) forming highly toxic and flammable $\mathrm{PH}_{3}$. It is still unclear whether future anode materials with high capacities, low desodiation potential, low cost, and acceptable safety can be developed that achieve performance comparable to that of graphite in LIBs.

\section{Magnesium-ion batteries}

A major handicap of conventional LIBs is that elemental $\mathrm{Li}$ cannot be used as the anode material because of safety issues. During repeated charging of such an LIB, Li is not deposited smoothly but instead forms dendrites, which can grow to the cathode side, leading to short-circuiting and possibly explosion of the cell. ${ }^{22}$ The great attraction of $\mathrm{Mg}$-ion batteries (MIBs) is the fact that metallic $\mathrm{Mg}$ does not form dendrites and can therefore be used safely as an anode in rechargeable batteries. ${ }^{23,24}$ Metallic $\mathrm{Mg}$ combines many important properties such as potentially high safety, low cost, non-toxicity, very high charge storage capacities $\left(2205 \mathrm{~mA} \mathrm{~h} \mathrm{~g}^{-1}, 3833 \mathrm{~mA} \mathrm{~h} \mathrm{~cm}^{-3}\right)$ and a low negative potential $(-2.37 \mathrm{~V}$ vs. SHE) making it an attractive anode. ${ }^{23,25-28}$ In contrast to typical anode materials, which require mixing with conductive additives and polymeric binders to fabricate electrodes, metallic $\mathrm{Mg}$ foil can be readily used as an anode material. However, despite all these advantages, the commercialization of MIBs has been hindered by the shortfall of efficient cathode materials and electrolyte limitations. Unlike Li- and Na-ions, which can be readily inserted into/extracted from conventional cathodes such as layered transition metal compounds, Mg-ions have strong Coulomb interactions with the host lattice because of their small radius and divalent charge, which leads to difficulties in insertion/ extraction reversibility, especially at reasonably high charge/ discharge rates. $^{29}$ The second problem is associated with the strong coordination of Mg-ions with solvent molecules, which leads to Mg-ion desolvation issues at the electrolytecathode interface that eventually hamper $\mathrm{Mg}$-ion insertion into the cathode. ${ }^{30-34}$ Subsequently, most known Mg-ion cathode materials are characterized by low rate capabilities and cyclabilities, as well as high discharge/charge voltage polarization. ${ }^{23,26,35-39}$ The Chevrel phase $\left(\mathrm{Mo}_{6} \mathrm{~S}_{8}\right)$ discovered by Aurbach et al. ${ }^{40}$ two decades ago remains the most wellknown $\mathrm{Mg}$-ion cathode. $\mathrm{Mo}_{6} \mathrm{~S}_{8}$ shows a specific chargestorage capacity of $110 \mathrm{~mA} \mathrm{~h} \mathrm{~g}^{-1}$ and discharge voltage of $\sim 1.2 \mathrm{~V} v s . \mathrm{Mg}^{2+} / \mathrm{Mg}$, yielding a theoretical energy density of $c a$. $126 \mathrm{~W} \mathrm{~h} \mathrm{~kg}^{-1}$ in combination with an $\mathrm{Mg}$ anode. In addition to the difficulty of finding suitable $\mathrm{Mg}$-ion cathodes, the development of MIBs is also limited by the electrolyte chemistry. For all types batteries one has to consider that the electrolyte is prone to reduction or oxidation at either very low or high potentials, respectively. The latter leads to the formation of a solidelectrolyte interface (SEI) layer with the decomposition products, consumption of $\mathrm{Li}($ or $\mathrm{Na}$ ) ions, and consequently irreversible capacity loss. In contrast to the case for LIBs and NIBs, Mg electrolytes such as highly reductive Grignard reagents or borohydrides for MIBs are stable at the potentials needed for $\mathrm{Mg}$ electroplating/stripping, and thus do not lead to the formation of an SEI layer on the anode side ( $\mathrm{Mg}$ foil). However, such compounds have limitations with respect to oxidation stability, which does not exceed 2-2.6 V vs. $\mathrm{Mg}^{2+} / \mathrm{Mg}$.

\section{Magnesium-sodium dual-ion batteries}

To overcome the poor performance of Mg-ion cathodes, yet harness the beneficial properties of a metallic $\mathrm{Mg}$ anode, a new dual-ion battery concept has recently been proposed. ${ }^{25,37,41-47}$ Such a battery combines a metallic $\mathrm{Mg}$ anode with an $\mathrm{Li}^{-}{ }^{41,42,47-56}$ or Na-ion ${ }^{46,57-59}$ cathode material and an electrolyte containing both $\mathrm{Mg}$ - and Li- or Na-ions, respectively. During discharge of such a battery, $\mathrm{Mg}$ metal is oxidized along with concomitant desolvation of $\mathrm{Mg}$-ions in the electrolyte, while $\mathrm{Na}$ - or Li-ions intercalate into the cathode material (Fig. 3). Because of the low abundance of Li salts, hybrid battery systems combining $\mathrm{Mg}$ and $\mathrm{Na}$ are favored over those with $\mathrm{Mg}$ and $\mathrm{Li}$. The great advantage of dual-ion batteries compared with conventional MIBs is the possibility to use high-performance Na-ion cathodes usually applied in SIBs. A major shortcoming of this type of battery is the low oxidative stability of $\mathrm{Mg} / \mathrm{Na}$ dual-ion electrolytes, which limits the working voltage range and therefore the energy density of dual-ion batteries. In addition, because of the non-rocking-chair operation principle of the dual-ion concept, and therefore the large mass/volume of the electrolyte needed for battery operation, the energy density of dual-ion battery systems is considerably lower than that for rocking-chair MIBs. Specifically, in the case of $\mathrm{Mg} / \mathrm{Na}$ dual-ion batteries, the anodic capacity associated with reversible $\mathrm{Mg}$ electrodeposition/stripping strongly depends on the concentration of $\mathrm{Mg}$-ions in the electrolyte, resulting in rather low celllevel energy densities of $10-60 \mathrm{~W} \mathrm{~h} \mathrm{~kg}^{-1}$. Therefore, the use of such batteries in commercial applications will most likely largely depend on finding highly concentrated $\mathrm{Mg} / \mathrm{Na}$ dualion electrolytes.

\section{Aluminum-ion and aluminum-graphite dual-ion batteries}

Similar to metallic $\mathrm{Mg}$, $\mathrm{Al}$ is a highly abundant, non-toxic, and inexpensive metal that can be used safely in rechargeable 


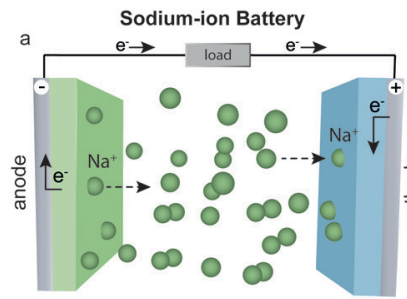

advantages:

- availability of $\mathrm{Na}$-ion cathode materials with performance comparable to state-of-the art Li-ion cathodes (2) - simple, safe electrolyte formulations

ס

- lack of efficient anode materials that combine safety, low cost and high energy density (metallic sodium is unsafe to use)

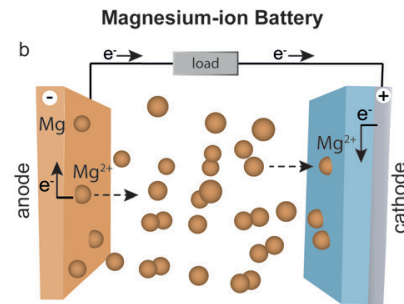

advantages: metallic magnesium can be safely used as anode material

disadvantage:

- lack of efficient cathode materials - electrolyte stability limited to ca. 2-2.6 V vs. $\mathrm{Mg}^{2+} / \mathrm{Mg}$, hence operational voltag a limited to low valus - electrolytes are potential safety issue - electrolytes are potential safety
(typically Grignard compounds)

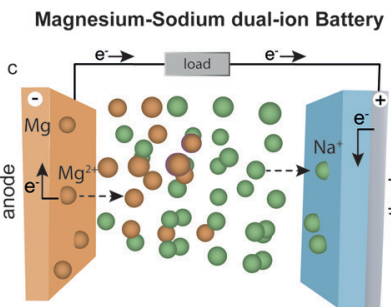
advantages:

- metallic magnesium can be safely used as anode material

- issue of poor Mg-ion cathode performance can be circumvented by combining magnesium with Na-ion cathode

disadvantages:

- concentration of $\mathrm{Na} / \mathrm{Mg}$-ions in the electrolyte is limiting factor for cell capacity

- electrolyte stability limited to ca 2 V vs. $\mathrm{Mg}^{2+} / \mathrm{Mg}$, hence operational voltages are Aluminum-ion Battery limited to low values

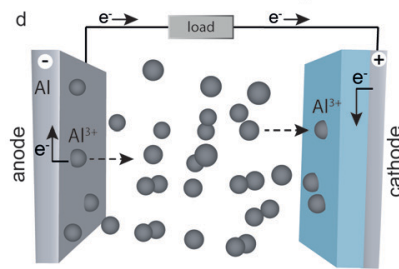

advantages:

- metallic aluminum can be safely used as anode material$$
\text { disadyantages: }
$$

- lack of efficient cathode materials due to strong interaction of Al-ions with host lattice

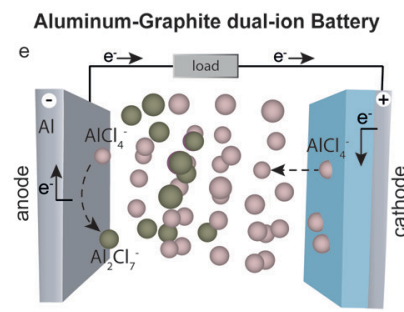

advantages:

- metallic aluminum can b used as on the anode side of the battery material

disadvantages:

- concentration of $\mathrm{Al}_{2} \mathrm{Cl}_{7}$; ions in the electrolyte is limiting factor for cell capacity

- electrolyte stability limited to ca. $2.5 \mathrm{~V}$ vs. Al3+/Al, hence operational

voltages are limited to low values

Fig. 3 Schematic working principle of sodium-ion (a), magnesium-ion (b), magnesium-sodium dual-ion (c), aluminum-ion (d), and aluminumgraphite dual-ion (e) batteries and the respective advantages and disadvantages of each system.

aluminum-ion batteries (AIBs) because of its dendrite-free electrodeposition. ${ }^{19}$ Furthermore, $\mathrm{Al}$ has extremely high volumetric and gravimetric capacities of $8046 \mathrm{~mA} \mathrm{~h} \mathrm{~cm}^{-3}$ and $2980 \mathrm{~mA} \mathrm{~h} \mathrm{~g}^{-1}$, respectively. However, the $\mathrm{Al}^{3+} / \mathrm{Al}$ redox potential is shifted to more positive value than that of the $\mathrm{Mg}^{2+} / \mathrm{Mg}$ couple (see also Fig. 2), resulting in lower overall cell voltage compared with that of MIBs. An additional complication is the fact that although efficient $\mathrm{Al}$ plating/stripping occurs in chloroaluminate ionic liquids, they are corrosive and often have a limited operation voltage window of about $2.5 \mathrm{~V}$. With respect to reversible Al-ion storage, various materials have been explored so far, such as sulfides, ${ }^{60-73}$ selenides, ${ }^{74,75}$ Prussian blue analogs, ${ }^{76,77}$ transition metal oxides, ${ }^{78-91}$ phosphite,${ }^{92}$ carbide, ${ }^{93}$ molybdite, ${ }^{94}$ vanadate, ${ }^{95}$ sulfur, ${ }^{96-98}$ selenium, ${ }^{99}$ iodine, ${ }^{100}$ and oxygen. ${ }^{101}$ Although reversible Al-ion storage has been demonstrated, most of the reported compounds showed relatively low charge-storage capacity, low average discharge voltage, high polarization, and short cycle life. Similar to the case for MIBs, the intercalation of Al-ions, which are much smaller than Li-ions, has proved to be difficult because of their strong coulombic interaction with the host cathode material. ${ }^{29}$ In this context, finding suitable Al-ion cathodes with high capacity and high operating voltage remains a great challenge.

Apart from AIBs, aluminum-graphite dual-ion batteries (Al-GDIBs) have attracted considerable attention recently. Al-GDIBs are composed of highly abundant elements $(\mathrm{H}, \mathrm{O}, \mathrm{N}, \mathrm{C}$, and $\mathrm{Al})$ and have appropriate energy densities $\left(30-70 \mathrm{~W} \mathrm{~h} \mathrm{~kg}^{-1}\right) .{ }^{102-106}$ The basic architecture of an Al-GDIB consists of a graphite cathode, metallic $\mathrm{Al}$ current collector, and $\mathrm{AlCl}_{3}$-1-ethyl-3-methylimidazolium chloride ([EMIM]Cl) ionic liquid anolyte, as shown in Fig. 3. Thus far, various forms of natural and synthetic graphite/carbon such as natural graphite flakes, ${ }^{107,108}$ kish graphite flakes, ${ }^{109}$ graphitic foams, ${ }^{102,110}$ graphene nanoribbons, ${ }^{111}$ few-layer graphene aerogels, ${ }^{112}$ graphene mesh network, ${ }^{113}$ large-sized few-layer graphene, ${ }^{114}$ and carbon paper (of graphitic nature) ${ }^{115-117}$ have been used as the cathode materials of Al-GDIBs, providing capacities of $60-150 \mathrm{~mA} \mathrm{~h} \mathrm{~g}^{-1}$, average discharge voltages of 1.7-2 V, and long-term cyclic stability for up to 10000 cycles. However, it should be noted that the working principle of such batteries is different from that of rocking-chair metal-ion batteries. In this battery concept, during charge, the following half-reactions occur at the positive and negative electrodes, respectively:

$$
\begin{gathered}
x \mathrm{C}+\mathrm{AlCl}_{4}^{-} \rightarrow \mathrm{C}_{x}\left[\mathrm{AlCl}_{4}\right]+\mathrm{e}^{-} \\
4 \mathrm{Al}_{2} \mathrm{Cl}_{7}^{-}+3 \mathrm{e}^{-} \rightarrow \mathrm{Al}+7 \mathrm{AlCl}_{4}{ }^{-}
\end{gathered}
$$

Reaction (4) represents the intercalation of $\mathrm{AlCl}_{4}{ }^{-}$species into the graphite cathode during its oxidation. Reaction (5), which occurs at the anode, relies on the presence of $\mathrm{Al}_{2} \mathrm{Cl}_{7}{ }^{-}$and is only observed in acidic melts (molar ratio of $\mathrm{AlCl}_{3}$ to $[\mathrm{EMIM}] \mathrm{Cl}>1$ ). During the charging process, $\mathrm{Al}$ species are depleted from the chloroaluminate ionic liquid and taken up by both electrodes. Therefore, severe limitations are imposed on the amount of chloroaluminate ionic liquid because it acts as a capacitylimiting liquid anode (anolyte). We note that graphite dual-ion batteries are not limited to the use of $\mathrm{Al}$ plating/stripping reactions on the negative electrode. ${ }^{118,119}$ Other presently pursued alternative anodes include graphite, ${ }^{120}$ carbonaceous materials, ${ }^{121-124} \mathrm{Sn},{ }^{125,126} \mathrm{Sb}^{125}$ or $\mathrm{Pb} .{ }^{125}$

\section{Conclusion and outlook}

Despite the fact that post-LIBs based on $\mathrm{Na}, \mathrm{Mg}$, or Al potentially offer substantial electrochemical and economic advantages, numerous challenges still hinder the practical utility and commercial deployment of these technologies. In short, enormous effort is required to develop low-cost Na-ion anodes that possess low desodiation potential and high charge-storage capacity to achieve comparable performance with that of graphite anodes 
in LIBs. The greatest challenges for MIBs and AliBs lie, however, in finding electrolytes with higher electrochemical oxidation stability and the development of cathode materials with high charge-storage capacity at high potentials. With respect to magnesium-sodium and aluminum-graphite dual-ion batteries, much room for improvement also remains regarding the gravimetrical and volumetric charge-storage capacities of electrolytes (anolytes), their cycle life, and oxidation stability. In the context of the effects of electrolytes, separators, and current collectors on the overall energy density of post-LIBs, further research should be focused on quantifying their practical amounts. Generally, batteries in academia are designed to test proof-of-principle and often neglect cost or the mass/volume of the entire battery (including all the inactive components). However, such factors are crucial for commercialization. The technological immaturity of these alternative battery systems in this regard makes it very difficult to predict which battery type might emerge as a commercial product. It should also be noted that none of the presented battery technologies is currently capable of competing with LIBs in terms of energy density and will most likely not be in the future. This is in stark contrast to Li-sulfur, Li-air or solid-state batteries with metallic lithium that are fuelled by the promise of higher energy density compared to the present state of the art. The prospective benefit of such non-Li-ion-based batteries might be-given their further optimization-as viable energy-storage systems for applications where parameters such as cost and environmental friendliness are more important than energy density.

\section{Conflicts of interest}

There are no conflicts to declare.

\section{Acknowledgements}

This research is part of the activities of SCCER HaE, which is financially supported by Innosuisse - Swiss Innovation Agency. This work was also financially supported by ETH Zürich (Grant No. ETH-56 12-2) and the Swiss Federal Commission for Technology and Innovation (CTI-Project No. 14698.2 PFIW-IW).

\section{Notes and references}

1 M. Pacesila, S. G. Burcea and S. E. Colesca, Renewable Sustainable Energy Rev., 2016, 56, 156-170.

2 S. Weitemeyer, D. Kleinhans, T. Vogt and C. Agert, Renewable Energy, 2015, 75, 14-20.

3 B. Huang, Z. Pan, X. Su and L. An, J. Power Sources, 2018, 399, 274-286.

4 G. Li, B. Huang, Z. Pan, X. Su, Z. Shao and L. An, Energy Environ. Sci., 2019, 12, 2030-2053.

5 J. C. Pramudita, D. Sehrawat, D. Goonetilleke and N. Sharma, Adv. Energy Mater., 2017, 7, 1602911.

6 C. Fang, X. Wang and Y. S. Meng, Trends Chem., 2019, 1, 152-158.
7 Y. Zhang, T.-T. Zuo, J. Popovic, K. Lim, Y.-X. Yin, J. Maier and Y.-G. Guo, Mater. Today, 2019, DOI: 10.1016/j.mattod. 2019.09.018.

8 X.-B. Cheng, R. Zhang, C.-Z. Zhao and Q. Zhang, Chem. Rev., 2017, 117, 10403-10473.

9 K. M. Abraham, J. Phys. Chem. Lett., 2015, 6, 830-844.

10 R. Berthelot, D. Carlier and C. Delmas, Nat. Mater., 2011, 10, 74-80.

11 Y.-U. Park, D.-H. Seo, H.-S. Kwon, B. Kim, J. Kim, H. Kim, I. Kim, H.-I. Yoo and K. Kang, J. Am. Chem. Soc., 2013, 135, 13870-13878.

12 M. Nose, H. Nakayama, K. Nobuhara, H. Yamaguchi, S. Nakanishi and H. Iba, J. Power Sources, 2013, 234, 175-179.

13 B. Jache and P. Adelhelm, Angew. Chem., Int. Ed., 2014, 53, 10169-10173.

14 H. Kang, Y. Liu, K. Cao, Y. Zhao, L. Jiao, Y. Wang and H. Yuan, J. Mater. Chem. A, 2015, 3, 17899-17913.

15 M. Walter, R. Erni and M. V. Kovalenko, Sci. Rep., 2015, 5, 8418.

16 C.-M. Park, J.-H. Kim, H. Kim and H.-J. Sohn, Chem. Soc. Rev., 2010, 39, 3115-3141.

17 B. Huang, Z. Pan, X. Su and L. An, J. Power Sources, 2018, 395, 41-59.

18 M. F. Oszajca, M. I. Bodnarchuk and M. V. Kovalenko, Chem. Mater., 2014, 26, 5422-5432.

19 J. Muldoon, C. B. Bucur and T. Gregory, Chem. Rev., 2014, 114, 11683-11720.

20 L. Tan and Y. Chi-lung, Int. Geol. Rev., 1970, 12, 778-786.

21 S. Wang, K. V. Kravchyk, A. N. Filippin, U. Müller, A. N. Tiwari, S. Buecheler, M. I. Bodnarchuk and M. V. Kovalenko, Adv. Sci., 2018, 5, 1700712.

22 S. Afyon, K. V. Kravchyk, S. Wang, J. v. d. Broek, C. Hänsel, M. V. Kovalenko and J. L. M. Rupp, J. Mater. Chem. A, 2019, 7, 21299-21308.

23 H. D. Yoo, I. Shterenberg, Y. Gofer, G. Gershinsky, N. Pour and D. Aurbach, Energy Environ. Sci., 2013, 6, 2265-2279.

24 K. V. Kravchyk, L. Piveteau, R. Caputo, M. He, N. P. Stadie, M. I. Bodnarchuk, R. T. Lechner and M. V. Kovalenko, ACS Nano, 2018, 12, 8297-8307.

25 S. Yagi, T. Ichitsubo, Y. Shirai, S. Yanai, T. Doi, K. Murase and E. Matsubara, J. Mater. Chem. A, 2014, 2, 1144-1149.

26 R. Mohtadi and F. Fuminori Mizuno, Beilstein J. Nanotechnol., 2014, 5, 1291-1311.

27 J. Liu, S. Wang, K. Kravchyk, M. Ibáñez, F. Krumeich, R. Widmer, D. Nasiou, M. Meyns, J. Llorca, J. Arbiol, M. V. Kovalenko and A. Cabot, J. Mater. Chem. A, 2018, 6, 10958-10966.

28 S. Wang, M. He, M. Walter, F. Krumeich, K. V. Kravchyk and M. V. Kovalenko, Nanoscale, 2018, 10, 6827-6831.

29 E. Levi, M. D. Levi, O. Chasid and D. Aurbach, J. Electroceram., 2009, 22, 13-19.

30 S. H. Lapidus, N. N. Rajput, X. Qu, K. W. Chapman, K. A. Persson and P. J. Chupas, Phys. Chem. Chem. Phys., 2014, 16, 21941-21945.

31 N. N. Rajput, T. J. Seguin, B. M. Wood, X. Qu and K. A. Persson, Top. Curr. Chem., 2018, 376, 19. 
32 R. Deivanayagam, B. J. Ingram and R. Shahbazian-Yassar, Energy Storage Mater., 2019, 21, 136-153.

33 M. Okoshi, Y. Yamada, A. Yamada and H. Nakai, J. Electrochem. Soc., 2013, 160, A2160-A2165.

34 L. F. Wan, B. R. Perdue, C. A. Apblett and D. Prendergast, Chem. Mater., 2015, 27, 5932-5940.

35 M. M. Huie, D. C. Bock, E. S. Takeuchi, A. C. Marschilok and K. J. Takeuchi, Coord. Chem. Rev., 2015, 287, 15-27.

36 P. Saha, M. K. Datta, O. I. Velikokhatnyi, A. Manivannan, D. Alman and P. N. Kumta, Prog. Mater. Sci., 2014, 66, 1-86.

37 K. V. Kravchyk, M. Walter and M. V. Kovalenko, Commun. Chem., 2019, $2,84$.

38 K. V. Kravchyk, R. Widmer, R. Erni, R. J. C. Dubey, F. Krumeich, M. V. Kovalenko and M. I. Bodnarchuk, Sci. Rep., 2019, 9, 7988.

39 R. J. C. Dubey, T. Colijn, M. Aebli, E. E. Hanson, R. Widmer, K. V. Kravchyk, M. V. Kovalenko and N. P. Stadie, ACS Appl. Mater. Interfaces, 2019, 11, 39902-39909.

40 D. Aurbach, Z. Lu, A. Schechter, Y. Gofer, H. Gizbar, R. Turgeman, Y. Cohen, M. Moshkovich and E. Levi, Nature, 2000, 407, 724-727.

41 Y. Cheng, Y. Shao, J.-G. Zhang, V. L. Sprenkle, J. Liu and G. Li, Chem. Commun., 2014, 50, 9644-9646.

42 J.-H. Cho, M. Aykol, S. Kim, J.-H. Ha, C. Wolverton, K. Y. Chung, K.-B. Kim and B.-W. Cho, J. Am. Chem. Soc., 2014, 136, 16116-16119.

43 S. Su, Z. Huang, Y. NuLi, F. Tuerxun, J. Yang and J. Wang, Chem. Commun., 2015, 51, 2641-2644.

44 H. D. Yoo, Y. Liang, Y. Li and Y. Yao, ACS Appl. Mater. Interfaces, 2015, 7, 7001-7007.

45 T. Ichitsubo, S. Okamoto, T. Kawaguchi, Y. Kumagai, F. Oba, S. Yagi, N. Goto, T. Doi and E. Matsubara, J. Mater. Chem. A, 2015, 3, 10188-10194.

46 M. Walter, K. V. Kravchyk, M. Ibáñez and M. V. Kovalenko, Chem. Mater., 2015, 27, 7452-7458.

47 T. Gao, F. Han, Y. Zhu, L. Suo, C. Luo, K. Xu and C. Wang, Adv. Energy Mater., 2015, 5, 1401507.

48 Y. Cheng, D. Choi, K. S. Han, K. T. Mueller, J.-G. Zhang, V. L. Sprenkle, J. Liu and G. Li, Chem. Commun., 2016, 52, 5379-5382.

49 Z. Zhang, H. Xu, Z. Cui, P. Hu, J. Chai, H. Du, J. He, J. Zhang, X. Zhou, P. Han, G. Cui and L. Chen, J. Mater. Chem. A, 2016, 4, 2277-2285.

50 R. Sun, C. Pei, J. Sheng, D. Wang, L. Wu, S. Liu, Q. An and L. Mai, Energy Storage Mater., 2018, 12, 61-68.

51 M. Rashad, X. Li and H. Zhang, ACS Appl. Mater. Interfaces, 2018, 10, 21313-21320.

52 X. Fan, R. R. Gaddam, N. A. Kumar and X. S. Zhao, Adv. Energy Mater., 2017, 7, 1700317.

53 Q. Miao, Y. NuLi, N. Wang, J. Yang, J. Wang and S.i. Hirano, $R S C A d v$., 2016, 6, 3231-3234.

54 Q. Fu, R. Azmi, A. Sarapulova, D. Mikhailova, S. Dsoke, A. Missiul, V. Trouillet, M. Knapp, N. Bramnik and H. Ehrenberg, Electrochim. Acta, 2018, 277, 20-29.

55 C. Bonatto Minella, P. Gao, Z. Zhao-Karger, T. Diemant, R. J. Behm and M. Fichtner, ChemistrySelect, 2017, 2, 7558-7564.
56 J. Tian, D. Cao, X. Zhou, J. Hu, M. Huang and C. Li, ACS Nano, 2018, 12, 3424-3435.

57 Y. Li, Q. An, Y. Cheng, Y. Liang, Y. Ren, C.-J. Sun, H. Dong, Z. Tang, G. Li and Y. Yao, Nano Energy, 2017, 34, 188-194.

58 J. Zeng, Z. Cao, Y. Yang, Y. Wang, Y. Peng, Y. Zhang, J. Wang and J. Zhao, Electrochim. Acta, 2018, 284, 1-9.

59 A. Rudola, S. A. B. Azmansah and P. Balaya, J. Electrochem. Soc., 2018, 165, A1092-A1094.

60 L. X. Geng, G. C. Lv, X. B. Xing and J. C. Guo, Chem. Mater., 2015, 27, 4926-4929.

61 Y. X. Hu, D. L. Ye, B. Luo, H. Hu, X. B. Zhu, S. C. Wang, L. L. Li, S. J. Peng and L. Z. Wang, Adv. Mater., 2018, 30, 1703824.

62 H. Li, H. Yang, Z. Sun, Y. Shi, H.-M. Cheng and F. Li, Nano Energy, 2019, 56, 100-108.

63 L. Wu, R. Sun, F. Xiong, C. Pei, K. Han, C. Peng, Y. Fan, W. Yang, Q. An and L. Mai, Phys. Chem. Chem. Phys., 2018, 20, 22563-22568.

64 X. F. Zhang, S. Wang, J. G. Tu, G. H. Zhang, S. J. Li, D. H. Tian and S. Q. Jiao, ChemSusChem, 2018, 11, 709-715.

65 Y. X. Hu, B. Luo, D. L. Ye, X. B. Zhu, M. Q. Lyu and L. Z. Wang, Adv. Mater., 2017, 29, 1606132.

66 K. Liang, L. Ju, S. Koul, A. Kushima and Y. Yang, $A d v$. Energy Mater., 2019, 9, 1802543.

67 Z. Li, B. Niu, J. Liu, J. Li and F. Kang, ACS Appl. Mater. Interfaces, 2018, 10, 9451-9459.

68 N. Takami and N. Koura, Electrochim. Acta, 1988, 33, 69-74.

69 S. Wang, Z. Yu, J. Tu, J. Wang, D. Tian, Y. Liu and S. Jiao, Adv. Energy Mater., 2016, 6, 1600137.

70 Z. Yu, Z. Kang, Z. Hu, J. Lu, Z. Zhou and S. Jiao, Chem. Commun., 2016, 52, 10427-10430.

71 L. X. Geng, J. P. Scheifers, C. Y. Fu, J. Zhang, B. P. T. Fokwa and J. C. Guo, ACS Appl. Mater. Interfaces, 2017, 9, 21251-21257.

72 V. V. Kulish, D. Koch and S. Manzhos, Phys. Chem. Chem. Phys., 2017, 19, 6076-6081.

73 S. Wang, S. Jiao, J. Wang, H.-S. Chen, D. Tian, H. Lei and D.-N. Fang, ACS Nano, 2017, 11, 469-477.

74 T. Cai, L. Zhao, H. Hu, T. Li, X. Li, S. Guo, Y. Li, Q. Xue, W. Xing, Z. Yan and L. Wang, Energy Environ. Sci., 2018, 11, 2341-2347.

75 J. Jiang, H. Li, T. Fu, B.-J. Hwang, X. Li and J. Zhao, ACS Appl. Mater. Interfaces, 2018, 10, 17942-17949.

76 L. D. Reed, S. N. Ortiz, M. Xiong and E. J. Menke, Chem. Commun., 2015, 51, 14397-14400.

77 S. Liu, G. L. Pan, G. R. Li and X. P. Gao, J. Mater. Chem. A, 2015, 3, 959-962.

78 S. Gu, H. Wang, C. Wu, Y. Bai, H. Li and F. Wu, Energy Storage Mater., 2017, 6, 9-17.

79 M. Chiku, H. Takeda, S. Matsumura, E. Higuchi and H. Inoue, ACS Appl. Mater. Interfaces, 2015, 7, 24385-24389.

80 H. Wang, Y. Bai, S. Chen, X. Luo, C. Wu, F. Wu, J. Lu and K. Amine, ACS Appl. Mater. Interfaces, 2015, 7, 80-84.

81 W. Wang, B. Jiang, W. Xiong, H. Sun, Z. Lin, L. Hu, J. Tu, J. Hou, H. Zhu and S. Jiao, Sci. Rep., 2013, 3, 3383.

82 J. Wei, W. Chen, D. Chen and K. Yang, J. Electrochem. Soc., 2017, 164, A2304-A2309. 
83 X. F. Zhang, G. H. Zhang, S. Wang, S. J. Li and S. Q. Jiao, J. Mater. Chem. A, 2018, 6, 3084-3090.

84 S. Liu, J. J. Hu, N. F. Yan, G. L. Pan, G. R. Li and X. P. Gao, Energy Environ. Sci., 2012, 5, 9743-9746.

85 Y. Liu, S. Sang, Q. Wu, Z. Lu, K. Liu and H. Liu, Electrochim. Acta, 2014, 143, 340-346.

86 W. Zhong, S. Sang, Y. Liu, Q. Wu, K. Liu and H. Liu, J. Power Sources, 2015, 294, 216-222.

87 T. Koketsu, J. Ma, B. J. Morgan, M. Body, C. Legein, W. Dachraoui, M. Giannini, A. Demortiere, M. Salanne, F. Dardoize, H. Groult, O. J. Borkiewicz, K. Chapman, P. Strasser and D. Dambournet, Nat. Mater., 2017, 16, 1142.

88 W. Q. Tang, J. Xuan, H. Z. Wang, S. L. Zhao and H. L. Liu, J. Power Sources, 2018, 384, 249-255.

89 S. Sang, Y. Liu, W. Zhong, K. Liu, H. Liu and Q. Wu, Electrochim. Acta, 2016, 187, 92-97.

90 H. Lahan, R. Boruah, A. Hazarika and S. K. Das, J. Phys. Chem. C, 2017, 121, 26241-26249.

91 S. Wang, K. V. Kravchyk, S. Pigeot-Rémy, W. Tang, F. Krumeich, M. Wörle, M. I. Bodnarchuk, S. Cassaignon, O. Durupthy, S. Zhao, C. Sanchez and M. V. Kovalenko, ACS Appl. Nano Mater., 2019, 2(10), 6428-6435.

92 J. Tu, H. Lei, M. Wang, Z. Yu and S. Jiao, Nanoscale, 2018, 10, 21284-21291.

93 A. VahidMohammadi, A. Hadjikhani, S. Shahbazmohamadi and M. Beidaghi, ACS Nano, 2017, 11, 11135-11144.

94 F. Nacimiento, M. Cabello, R. Alcántara, C. Pérez-Vicente, P. Lavela and J. L. Tirado, J. Electrochem. Soc., 2018, 165, A2994-A2999.

95 J. Jiang, H. Li, J. Huang, K. Li, J. Zeng, Y. Yang, J. Li, Y. Wang, J. Wang and J. Zhao, ACS Appl. Mater. Interfaces, 2017, 9, 28486-28494.

96 H. Yang, L. Yin, J. Liang, Z. Sun, Y. Wang, H. Li, K. He, L. Ma, Z. Peng, S. Qiu, C. Sun, H.-M. Cheng and F. Li, Angew. Chem., Int. Ed., 2018, 57, 1898-1902.

97 Y. Bian, Y. Li, Z. Yu, H. Chen, K. Du, C. Qiu, G. Zhang, Z. Lv and M.-C. Lin, ChemElectroChem, 2018, 5, 3607-3611.

98 G. Cohn, L. Ma and L. A. Archer, J. Power Sources, 2015, 283, 416-422.

99 X. Huang, Y. Liu, C. Liu, J. Zhang, O. Noonan and C. Yu, Chem. Sci., 2018, 9, 5178-5182.

100 S. Zhang, X. Tan, Z. Meng, H. Tian, F. Xu and W.-Q. Han, J. Mater. Chem. A, 2018, 6, 9984-9996.

101 L. Wang, F. Liu, W. Wang, G. Yang, D. Zheng, Z. Wu and M. K. H. Leung, RSC Adv., 2014, 4, 30857-30863.

102 M.-C. Lin, M. Gong, B. Lu, Y. Wu, D.-Y. Wang, M. Guan, M. Angell, C. Chen, J. Yang, B.-J. Hwang and H. Dai, Nature, 2015, 520, 324-328.
103 K. V. Kravchyk and M. V. Kovalenko, Adv. Energy Mater., 2019, 9, 1901749.

104 L. Fu, N. Li, Y. Liu, W. Wang, Y. Zhu and Y. Wu, Chin. J. Chem., 2017, 35, 13-20.

105 M. Zhang, X. Song, X. Ou and Y. Tang, Energy Storage Mater., 2019, 16, 65-84.

106 Y. Hu, D. Sun, B. Luo and L. Wang, Energy Technol., 2019, 7, 86-106.

107 M. Angell, C.-J. Pan, Y. Rong, C. Yuan, M.-C. Lin, B.-J. Hwang and H. Dai, Proc. Natl. Acad. Sci. U. S. A., 2017, 114, 834-839.

108 K. V. Kravchyk, S. Wang, L. Piveteau and M. V. Kovalenko, Chem. Mater., 2017, 29, 4484-4492.

109 S. Wang, K. V. Kravchyk, F. Krumeich and M. V. Kovalenko, ACS Appl. Mater. Interfaces, 2017, 9, 28478-28485.

110 Y. Wu, M. Gong, M.-C. Lin, C. Yuan, M. Angell, L. Huang, D.-Y. Wang, X. Zhang, J. Yang, B.-J. Hwang and H. Dai, Adv. Mater., 2016, 28, 9218-9222.

111 X. Yu, B. Wang, D. Gong, Z. Xu and B. Lu, Adv. Mater., 2017, 29, 1604118.

112 H. Chen, F. Guo, Y. Liu, T. Huang, B. Zheng, N. Ananth, Z. Xu, W. Gao and C. Gao, Adv. Mater., 2017, 29, 1605958.

113 G. Y. Yang, L. Chen, P. Jiang, Z. Y. Guo, W. Wang and Z. P. Liu, RSC Adv., 2016, 6, 47655-47660.

114 L. Zhang, L. Chen, H. Luo, X. Zhou and Z. Liu, Adv. Energy Mater., 2017, 7, 1700034.

115 S. Jiao, H. Lei, J. Tu, J. Zhu, J. Wang and X. Mao, Carbon, 2016, 109, 276-281.

116 H. Sun, W. Wang, Z. Yu, Y. Yuan, S. Wang and S. Jiao, Chem. Commun., 2015, 51, 11892-11895.

117 Y. Song, S. Jiao, J. Tu, J. Wang, Y. Liu, H. Jiao, X. Mao, Z. Guo and D. J. Fray, J. Mater. Chem. A, 2017, 5, 1282-1291.

118 M. Wang and Y. Tang, Adv. Energy Mater., 2018, 8, 1703320.

119 T. Placke, A. Heckmann, R. Schmuch, P. Meister, K. Beltrop and M. Winter, Joule, 2018, 2, 2528-2550.

120 L. Fan, Q. Liu, S. Chen, K. Lin, Z. Xu and B. Lu, Small, 2017, 13, 1701011.

121 X. Wang, C. Zheng, L. Qi and H. Wang, Glob. Chall., 2017, 1, 1700055.

122 X. Wang, L. Qi and H. Wang, J. Electrochem. Soc., 2017, 164, A3649-A3656.

123 B. Ji, F. Zhang, N. Wu and Y. Tang, Adv. Energy Mater., 2017, 7, 1700920.

124 L. Fan, Q. Liu, S. Chen, Z. Xu and B. Lu, Adv. Energy Mater., 2017, 7, 1602778.

125 M. Sheng, F. Zhang, B. Ji, X. Tong and Y. Tang, Adv. Energy Mater., 2017, 7, 1601963.

126 B. Ji, F. Zhang, X. Song and Y. Tang, Adv. Mater., 2017, 29, 1700519. 